\title{
The Completeness of The Contents of Dental Records at Private Dental Practice in Bandung
}

\author{
Grace Monica \\ Department of Dental Public Health \\ Faculty of Dentistry, Maranatha Christian University \\ Bandung, Indonesia \\ gracemonicasantoso@gmail.com
}

\author{
Jeannette Halim \\ Student \\ Faculty of Dentistry, Maranatha Christian University \\ Bandung, Indonesia
}

\author{
Ignatius Setiawan \\ Department of Dental Public Health \\ Faculty of Dentistry, Maranatha Christian University \\ Bandung, Indonesia
}

\begin{abstract}
A complete dental record can be used in solving legal cases as well as forensic cases in dentistry. The Government of the Republic of Indonesia has established a minimum standard of filling dental records. A cross sectional study was conducted to determine the completeness of the contents of dental records at private dental practice in Bandung. The total of 97 dental records were taken from 30 private dental practices of general dentists or dental specialists in the city of Bandung, taken by random sampling technique. This study showed that $70 \%$ of dental records did not fill in the odontogram section, $51 \%$ of dental records did not fill in the results of anamnesis, and the entire dental records did not fill in the physical examination section. As a conclusion, the average percentage of the completeness of dental record at private dental practices in Bandung was $62 \%$.
\end{abstract}

Keywords-dental record, private dental practice

\section{INTRODUCTION}

Dental records are a systematic documentation of a patient's dental health history by means of health care. The purpose of making the dental records is to provide a general description of the patient's dental conditions, as a legal document, as the patient's dental resumes both for the benefit of patients and referrals, as the basic of treatment planning/the needs of dental materials through calculation of DMF-T, as research materials, as a means of identifications [1].

Many victims of criminal and accident cases might be identified by dental identification. In 1477, a war victim was identified by the teeth. A murder victim who has been buried for six years, was identified from the dental chart made at the clinic [2]. According to KKI (Indonesian Medical Council), medical or dental records are useful in patient treatments, improvement of service qualities, education and researches, financials, health statistics, legal proofing, discipline and ethics.

The Government of Republic of Indonesia through the Indonesian Medical Council has compiled the Medical Record Manual Book and Dental Record Guidance Book. Dental record is divided into 4 (four) main part: patient identity, odontogram, treatment tables, attachment/supporting files such as x-ray radiography, laboratory result, informed consent, etc. The Ministry of Health of the Republic of Indonesia had previously prepared the National Standard for Dental Record in 2007, which described that in dental record, the part that should not be missing is the patient identity, general condition of the patient, odontogram, dental treatments, and identity of the dentist [3].

Indonesian Statute No. 29 in 2004 of Medical Practice subsection 46 (1) states that "Every doctor and dentist who performs medical practice is obliged to make medical records" [4]. The medical records main problem is when doctors and dentists do not fully aware the benefits of medical nor dental record. Filling up a complete dental record takes a long time and needs a good setting without omit the patient's chief complaint. The purpose of this study was to determine the contents of dental records at private dental practice in Bandung.

\section{MATERIALS AND METHODS}

This research was a descriptive analytic with cross sectional design. Population of this research was dental records at private dental practices in Bandung. The research was conducted by observing the completeness of the content of dental records. The sample of this study was 97 dental records randomly collected from 30 private dental practices in Bandung. Private dental practice chosen on this research was dental clinic which administered and run by a dentist. The samples were dental records between year 2011-2016, in good condition, and could be read clearly.

The results were obtained by using a prepared checklist based on the National Standard of Dental Record and Dental Record Guidance Book to check the completeness of the contents of dental record. When the item on dental record was filled, it would be scored as 1 , and if the item is not filled, it would be scored as 0 .

The ethical clearance was obtained from the Research Ethics Commission of the Faculty of Medicine of Maranatha Christian University-Immanuel 
Hospital with due observance of the basic principles of research ethics, based on Decree No. 192/KEP/III/2017.

\section{RESULTS}

Some private dental practices added items to their dental record format, such as religion, education, father's name, mother's name, type of payment, hours of visit, and office address. Number 1-8 in Table I is the patient's identity data, number 9 is the odontogram data, number 10 is the patient's general condition, number 11 is the investigation data, number $12-16$ is the examination/ treatment data, number 17 is the identity of the dentist. The result shows that on all dental record sampled, all dentists fill in patient's name, date of visit, and diagnosis of the diseases. The part of dental record which not fully equipped was the ethnic and physical examination. Table I also showed that only $49 \%$ dentist listed the results of anamnesis, $60 \%$ listed the treatment plans, $27 \%$ filled the odontogram, and only $66 \%$ give their signature on the dental record.

\section{TABLE I. THE COMPLETENESS OF DENTAL RECORDS}

\begin{tabular}{|c|c|c|c|c|c|}
\hline \multirow{2}{*}{ Variable } & \multicolumn{4}{|c|}{ Total } & \multirow[t]{2}{*}{ Category } \\
\hline & Yes & $\%$ & No & $\%$ & \\
\hline $\begin{array}{l}\text { Number of dental } \\
\text { record }\end{array}$ & 90 & 93 & 7 & 7 & \multirow[t]{8}{*}{ Patient's identity } \\
\hline Patient's name & 97 & 100 & 0 & 0 & \\
\hline $\begin{array}{l}\text { Place and date of } \\
\text { birth }\end{array}$ & 94 & 97 & 3 & 3 & \\
\hline Sex & 59 & 61 & 38 & 39 & \\
\hline Address & 90 & 93 & 7 & 7 & \\
\hline Ethnic & 0 & 0 & 97 & 100 & \\
\hline Occupation & 22 & 23 & 75 & 77 & \\
\hline Date of visit & 97 & 100 & 0 & 0 & \\
\hline Odontogram & 29 & 30 & 68 & 70 & Odontogram \\
\hline $\begin{array}{l}\text { Physical } \\
\text { Examination }\end{array}$ & 0 & 0 & 97 & 100 & $\begin{array}{l}\text { Patient's general } \\
\text { circumstances }\end{array}$ \\
\hline $\begin{array}{l}\text { Additional } \\
\text { examination }\end{array}$ & 17 & 18 & 80 & 82 & $\begin{array}{c}\text { Additional } \\
\text { examination }\end{array}$ \\
\hline Anamnesis & 48 & 49 & 49 & 51 & \multirow[t]{5}{*}{ Therapy } \\
\hline Diagnoses & 97 & 100 & 0 & 0 & \\
\hline Treatment planning & 58 & 60 & 39 & 40 & \\
\hline Therapy & 97 & 100 & 0 & 0 & \\
\hline Informed Consent & 59 & 61 & 38 & 39 & \\
\hline Dentist' signature & 64 & 66 & 33 & 34 & Dentist's identity \\
\hline
\end{tabular}

Table II showed the average of dental record completeness score was 10,5 or $62 \%$ complete. In this study, the patients name and the dental records number was obtained $100 \%$ from all the dental records.

TABLE II. DENTAL RECORD COMPLETENESS SCORE

\begin{tabular}{|c|c|}
\hline Total Score & \% \\
\hline 13 & 76 \\
\hline 12 & 71 \\
\hline 12 & 71 \\
\hline 12 & 71 \\
\hline 9 & 53 \\
\hline 10 & 59 \\
\hline 10 & 59 \\
\hline 10 & 59 \\
\hline 13 & 76 \\
\hline 13 & 76 \\
\hline 13 & 76 \\
\hline 7 & 76 \\
\hline
\end{tabular}

\begin{tabular}{|c|c|}
\hline Total Score & $\%$ \\
\hline 8 & 47 \\
\hline 8 & 47 \\
\hline 9 & 53 \\
\hline 11 & 65 \\
\hline 11 & 65 \\
\hline 8 & 47 \\
\hline 7 & 41 \\
\hline 13 & 76 \\
\hline 13 & 76 \\
\hline 13 & 76 \\
\hline 8 & 47 \\
\hline 6 & 35 \\
\hline 9 & 53 \\
\hline 10 & 59 \\
\hline 9 & 53 \\
\hline 12 & 71 \\
\hline 13 & 76 \\
\hline 12 & 71 \\
\hline 10 & 59 \\
\hline 9 & 53 \\
\hline 10 & 59 \\
\hline 13 & 76 \\
\hline 13 & 76 \\
\hline 13 & 76 \\
\hline 7 & 41 \\
\hline 6 & 35 \\
\hline 6 & 35 \\
\hline 8 & 47 \\
\hline 9 & 53 \\
\hline 10 & 59 \\
\hline 7 & 41 \\
\hline 13 & 76 \\
\hline 13 & 76 \\
\hline 6 & 35 \\
\hline 7 & 41 \\
\hline 7 & 41 \\
\hline 9 & 53 \\
\hline 9 & 53 \\
\hline 8 & 47 \\
\hline 9 & 53 \\
\hline 13 & 76 \\
\hline 13 & 76 \\
\hline 13 & 76 \\
\hline 13 & 76 \\
\hline 7 & 41 \\
\hline 7 & 41 \\
\hline 13 & 76 \\
\hline 12 & 71 \\
\hline 13 & 76 \\
\hline 12 & 71 \\
\hline 13 & 76 \\
\hline 10 & 59 \\
\hline 9 & 53 \\
\hline 8 & 47 \\
\hline 8 & 47 \\
\hline 13 & 76 \\
\hline 13 & 76 \\
\hline 13 & 76 \\
\hline 13 & 76 \\
\hline 10 & 59 \\
\hline 11 & 65 \\
\hline 11 & 65 \\
\hline 12 & 71 \\
\hline 9 & 53 \\
\hline 8 & 47 \\
\hline 8 & 47 \\
\hline 13 & 76 \\
\hline 13 & 76 \\
\hline 13 & 76 \\
\hline 13 & 76 \\
\hline
\end{tabular}




\begin{tabular}{|c|c|}
\hline Total Score & \% \\
\hline 9 & 53 \\
\hline 10 & 59 \\
\hline 13 & 76 \\
\hline 13 & 76 \\
\hline 8 & 47 \\
\hline 9 & 53 \\
\hline 8 & 47 \\
\hline 8 & 47 \\
\hline 9 & 53 \\
\hline 13 & 76 \\
\hline 13 & 76 \\
\hline 13 & 76 \\
\hline 13 & 76 \\
\hline 13 & 76 \\
\hline 10,5 & 62 \\
\hline
\end{tabular}

\section{DISCUSSION}

According to the 2007 National Standard of Dental Records, there were some important data to be recorded, such patient's identity, patient's general condition, odontogram, dental care data, and dentist's signature or name [3]. By Regulation of The Minister of Health of Republic of Indonesia Number 269/MENKES/PER/III/2008 for outpatients, medical records shall at least contain identity of patient, date and time of treatment, results of anamnesis, results of physical examination and additional examinations, diagnosis, treatment plan, and other services provided to patient, odontogram and informed consent whereas in Dental Record Guidance Book. Data should be included on dental record are patient identity consists of two parts such as patient's name and patient's medical history that should be noticed during the treatment, odontogram and dental care tables consisting of dates, nomenclature of the treated teeth, chief complaints/ diagnoses, the code of ICD 10, treatment, dentist's signature, and some necessary description $[3,5]$.

Dental record number is a permanent identification number for the administrative staff and as the dental record identification number used to store the dental records in which patient data varies.

Patient's name on medical or dental record shows person's identity data which can distinguish one patient to another, in this study the patient's name found was $100 \%$ of the 97 dental records examined. The sex of the patient is one of the characteristics or data of one's identity and to identify one. Gender can also serve as one of data to make decisions in diagnosis or treatment. In addition, it can also serve as epidemiological data of disease that served for education and research. In this study we can see $61 \%$ of dentists write the gender on the sheet of his dental record.

Place and date of birth is one of the identities which will not change and is useful for identifying patients. Date of birth can determine age of a person, therefore, the age data will serve to make decisions in diagnosing or in determining the treatment. In addition, age may also serve as data to determine the epidemiology of a disease that can be used for other research data. In this research, it was found that $97 \%$ dental record is filled with patient's place and date of birth.
In this study the patient's address is filled $93 \%$ of the total data. Otherwise, $100 \%$ dental record form do not has ethnic/race and phone number columns. The completeness of content of dental record in Bandung based on the categories listed in the National Standard of Dental Record 2007, Regulation of the Minister of Health of the Republic of Indonesia Number 269/MENKES/PER/III/2008, and Dental Record Guidance Book has not met the completeness criteria on the odontogram aspect $(73 \%)$, the general condition of the patient $(100 \%)$, and the additional examination $(82 \%)$. The other aspects still need to be equipped although the number is not as much on the aspects that have been mentioned formerly.

The differences that appear in dental records format in 2007 and 2015 are additional demand for Population Identity Number and ethnic/race data. This causes the absence of Population Identity Number and tribal/race data. It is likely that most private dental practice in Bandung still using the 2007 format of dental record.

Most of private dental practices in Bandung do not fill the odontogram format (73\%), and in all dental records sampled there is no completeness in terms of physical examinations. Institutions such as hospitals are usually more assertive in handling the matter because it will be related to Hospital Accreditation, but for private dental practices still need socialization and motivation to complete the odontogram part of the dental record.

The recording of a physical examination on a dental record is required to look at the history of a person's illness and to be useful in making treatment decisions. Odontogram, which is a map about the state of the tooth in the mouth, contains information which is not easily changed. An examination of the entire state of the patient's mouth is performed and recorded on the first visit so as to give an overall picture of the situation. The data on the odontogram should be renewed once a year [1]. Therefore, the dentist should spend more time on patients who make first visit to the clinic. After treating the chief complaints, the dentist can fill the odontogram and can provide dental health education in patients.

The conclusion of this study is the average percentage of the completeness of dental record at private dental practices in Bandung was $62 \%$.

\section{ACKNOWLEDGMENT}

The authors thank to the dentists who have been willing to examine the completeness of the dental record.

\section{REFERENCES}

[1] Panduan Rekam Medik Kedokteran Gigi. In: Indonesia KKR, 2015.

[2] E.J. Ryan, "Identification through dental records," Journal of Criminal Law and Criminology, vol. 28(2), 1937.

[3] Direktorat Jenderal Bina Pelayanan Medik Departemen Kesehatan RI, Standar rekam medik kedokteran gigi, 2007

[4] Undang-Undang Republik Indonesia nomor 29 tahun 2004 tentang praktik kedokteran, 2004

[5] Peraturan Menteri Kesehatan Republik Indonesia No. 269/MENKES/PER/III/2008 